надання медичної допомоги в післяпологовому періоді $21,88 \%$, проводити діагностику та визначати тактику при інфекціях, що передаються статевим шляхом 21,65\% сімейних лікарів;

2) невідповідність матеріально-технічної бази сімейних лікарських амбулаторій до надання сімейними лікарями акушерсько-гінекологічної допомоги в повному обсязі: табель оснащення сімейних амбулаторій не включає необхідне оснащення та вироби медичного призначення;

3) неготовність жінок до отримування повного обсягу акушерсько-гінекологічної допомоги у сімейних лікарів: 35,3\% жінок не довіряють сімейним лікарям та визначають рівень їх професійних компетенцій низьким;

4) зацікавленість лікарів акушерів-гінекологів у наданні повного обсягу медичної допомоги жінкам.

3 метою рішення даної проблеми та забезпечення інтеграції акушерсько-гінекологічної допомоги жінкам на первинний рівень надання медичної допомоги запропоновано комплекс заходів на державному та регіональному рівнях, які полягають в наступному:

- На державному рівні. Удосконалити нормативну базу 3 питань інтеграції акушерсько-гінекологічної допомоги на первинний рівень в тому числі розширити програми підготовки сімейних лікарів 3 питань акушерства та гінекології на до дипломному та післядипломному рівнях підготовки, розширити табель оснащення сімейних амбулаторій включивши оснащення та вироби медичного призначення необхідні для надання акушерсько-гінекологічної допомоги.

- На регіональному рівні. Необхідно забезпечити безперервну професійну підготовку сімейних лікарів 3 питань акушерства та гінекології на базі обласних тренінгових центрів 3 питань сімейної медицини, забезпечити сімейні амбулаторії необхідним оснащенням та засобами медичного призначення, впровадити місцеві економічні стимули для залучення сімейних лікарів до забезпечення жінок повним комплексом акушерськогінекологічної допомоги.

Висновки. Запровадження рекомендованих заходів буде забезпечувати більш ефективній інтеграції акушерсько-гінекологічної допомоги жінкам на первинний рівень надання медичної допомоги та підвищення рівня іiі доступності.

Іваньо Н.В., Росул М.М., Кошмякова Т.В., Корабельщикова М.О.

\title{
Сучасні тенденції лікування хворих інфарктом міокарда та динаміка смертності від данної патології в м. Ужгород
}

ДВНЗ «Ужгородський національний університет», факультет післядипломної освіти та доуніверситетської підготовки, кафедра терапії та сімейної медицини, м. Ужгород, Україна

На сьогоднішній день стан здоров'я населення України характеризується низьким рівнем тривалості життя, високими показниками захворюваності та смертності. Вагомий внесок у ці процеси вносить ішемічна хвороба серця (IXC) як складова частина серцевосудинних захворювань і яка $\epsilon$ на другому місці після артеріальної гіпертензії за поширеністю. Саме IXC є тим плацдармом, на якому розвиваються важкі серцево судинні ускладнення, зокрема інфаркт міокарда (IM). Поширеність IM, починаючи 32015 та по 2017 pp. в Україні коливалась, але залишалась на високому рівні (з 2018 р дані про поширеність хвороб і захворюваність відсутні у зв’язку із скасуванням Форми №20 згідно наказу MO3 України). Разом 3 тим спостерігається позитивна тенденція до зменшення смертності від IM.

Мета - проаналізувати запровадження коронаровентрикулографії (КВГ) та перкутанних коронарних втручань (ангіопластики/стентування інфаркт-зележної коронарної артерії) у хворих IМ в м. Ужгороді за 2015, 2019 рр. та динаміку смертності від даної патології.
Матеріали та методи. Обстежено 60 хворих, які перенесли нефатальний IM у 2015 році та 71 хворий в 2019 році, яким в ургентному порядку проводилась КВГ та за показами стентування коронарних артерій (КА) або рекомендувалось хірургічне лікування - шунтування. Вивчено структуру смертності хворих IM за 2015 та 2019 роки.

Результати. В 2015 році перенесли нефатальний IM 154 хворих. Всього було проведено КВГ 60 хворим, що склало $39,0 \%$ від всіх виживших хворих. В ургентному порядку було проведено КВГ 54 хворим $(35,1 \%)$, в плановому порядку - 6 хворим (3,9\%). В 2019 році перенесли нефатальний IM значно менша кількість хворих - 134 осіб. Разом з тим значно більшій кількості хворих було проведено КВГ - 71 хворим (53,0\%). Одночасно відбулося збільшення кількості хворих, яким КВГ проводилось як в ургентному (63 хворих або 47,0\%) так і в плановому (8 хворих або 6,0\%) порядку.

За результатами отриманих після КВГ даних в 2015 році проведено стентувань КА 57 хворим (37,0\%). Стентування КА в більшості випадків проводилось 
хворим IM в ургентному порядку - 52 хворим $(33,8 \%)$. В плановому порядку стентування КА проведено тільки 5 хворим (3,2\%). В 2019 р значно збільшилась кількість хворих IM, яким було проведено стентування КА (66 хворим або 49,3\%) як в ургентному (61 хворий або 45,5\%) так і в плановому порядку (5 хворим або 3,7\%). За результатами отриманих після КВГ даних у зв'язку із значним ураженням КА було рекомендовано хірургічне лікування практично однаковій кількості хворих: в 2015 р. 6 хворим або 3,9\%, в 2019 році - 5 хворим або 3,7\%. В 2015 році померло від IM 63 хворих, що склало 29,0\% від всіх зареєстрованих хворих з ІМ. Під час стаціонарного лікування померло від IM 42 хворих або 19,4\%. На догоспітальному етапі в 2 рази менше - 21 хворий або 9,7\%. В 2019 році спостерігалась цікава тенденція відносно смертності від IM: в абсолютних цифрах кількість хворих з фатальним IM зменшилась (померло 56 хворих або 29,5\%), однак враховуючи скорочення чисельності дорослого населення в м. Ужгороді показник смертності від IM на 1000 дорослого населення практично не змінився. Разом $з$ тим спостерігалась вкрай негативна тенденція до збільшення кількості хворих, які померли вдома. Так, під час стаціонарного лікування померло 20 хворих або 10,5\%, а на догоспітальному етапі 36 хворих або $19,0 \%$. Таким чином в стаціонарі померло майже в 2 рази менше хворих, одночасно вдома - в 2 рази більше. Це вкрай небезпечна тенденція оскільки під час стаціонарного лікування хворий отримує адекватне лікування IM у зв'язку з чим зменшується вірогідність фатального наслідку.

Висновки. За останні 5 років спостерігається чітка тенденція до збільшення кількості хворих IM, яким проводиться КВГ та найбільш ефективний сучасний метод реперфузії міокарда - стентування. Переважають хворі IM, яким дані втручання проводять в ургентному порядку, що дозволяє зберегти життя хворих та покращити їх прогноз. Смертність хворих від IM залишається на високому piвні. Виявлена небезпечна тенденція до збільшення кількості хворих, які помирають на догоспітальному етапі. Багато випадків таких смертей можна було би попередити при своєчасній діагностиці та якісному лікуванні.

Ключові слова: інфаркт міокарда, коронаровентрикулографія, смертність.

Примітка. У статтях збережено орфографію, пунктуацію та стилістику авторів. 